\title{
浅谈高中英语教学中学生人文素养的培养
}

\author{
刘孟 \\ 黔西县第一中学 \\ DOI:10.32629/er.v2i8.1976
}

[摘 要] 语言是人们是日常生活中十分重要的交流工具,人类文明的发展历程很大程度上也是语言的发展过程。语言不仅是 信息的载体,同时也是文化的载体,其中蕴含有十分深厚的文化底蕴。因此, 人类在学习一门语言时,其实远远不只是在学习它的 发音和方法, 同时也是在学习一种文化, 即要了解语言人内涵, 也要吸收这门语言中所蕴含的优良文化。现阶段, 我国高中教育机 构无一例外地十分重视英语教学工作,其根本目的一方面在于满足国内社会、经济、文化的发展需求, 另一方面也要对外培养 出一批高质量的英语专业人才。随着我国教育体系改革的不断深入,新形势下的英语教学工作既十分重视学生英语基础知识 和应用能力训练, 同时也十分关注学生综合素质的提升。高中教育机构在落实英语教学工作的过程中, 加强学生人文素质方面 的培养已经成为未来必然的发展趋势。

[关键词] 人文素养; 高中英语; 实践培养; 综合素质

人类社会发展到今天, 无论在工业化还是在信息化方面 都取得了空前的发展与进步, 以经济全球化为主要特征的和 平发展趋势不可逆转, 高水平的英语人才在世界各国都被看 作为稀缺资源, 即使是在英语国家, 也普遍十分重视具备英 语能力的非英文母语人才 ${ }^{[1]}$ 。然而, 当前我国高中教育机构 由于长期受到应试教育思维的影响, 提高升学率一直以来都 是所有教学工作的首要任务, 在学生人文素养的培养工作方 面还有很多工作要做。因此, 新形势下的英语教学工作应当 充分发挥英语科目的教学特点, 将人文素养培育与英语教学 工作有机结合起来, 不断提升学生们的综合素质, 这对于专 业英语人才的培养也有着不可替代的重要作用。

1 高中教育机构在学生人文素质培养方面普遍存在的 问题

1. 1 传统课堂人文氛围缺失

由于受到商业化社会环境与应试教育的影响, 现阶段我 国绝大多数高中教育机构在办学过程中都缺乏对于人文素 质培养的重视, 甚至根本不教育融入合作人文元素, 致使高 中英语课堂完全成为攻略考试题目的战场, 人文氛围完成无 从谈起。另外, 大多数的高中英语课堂都以课本教材为导向 开展教学活动, 但其十分主动地忽略教材中与人文教育相关 的内容 ${ }^{[2]}$ 。这种 “捞干的” 的教学方式直接造成课堂缺乏生 机, 学生学习的自主性全靠 “觉悟”, 致使课堂教学效率面临 巨大的瓶颈。

\section{2 人文氛围建设重视程度不够}

教师是培养学生人文素质的主力军, 尤其是在英语教 学中, 教师所发挥的作用更加直观且深刻。也就是说, 将人 文素养与英语教学工作有机结合起来, 关键在于发挥教师 的作用 ${ }^{[3]}$ 。然而, 现阶段, 我国大多数高中教育机构往往以灌 输知识为主要工作, 英语课堂上绝大多数教学工作都以提高 考试分数为核心, 这种欠缺人文素养的教学方式, 使得任课 教师不愿意在现有教学内容的基础上, 向培养学生人文素质
的方向进行延伸。

\section{3 对于人文内涵挖掘程度不足}

当前我国的高中英语教育无论在内容上还是在编排上 都已经十分成熟, 其中所涉及到的社会文人与国外风土文化 是十分完善且详尽的, 但在具体的教学工作中还需要任课教 师在掌握教材知识内容的基础上, 对其中的人文元素进行深 入的挖掘, 同时也要为学生提供全面的讲解 ${ }^{[4]}$ 。但由于任课 教师对于人文素养教育的重要性缺乏认识, 致使学生只能够 单一地了解英文的语法和发音, 对于英语文化几乎一无所知, 难以体会到英语的独特鬼力。

\section{4英语第二课堂未得到发展}

在45分钟的课堂教学时间内, 无论是教师的教学还是学 生的学习, 任务都是比较繁重的。实际上, 许多任课教师并没 有充分的时间来深挖教材内容, 无法对英语文化进行充分的 讲解, 致使人文素质的培养长期受到教学时长的限制。因此, 新形势下的英语教学工作, 应当进一步改善英语教学的时间 结构, 专门为英语文化教学开辟第二课堂, 为学生人文素质的 培养投入更多的时间 ${ }^{[5]}$ 。然而, 就高中英语教学的现状来看, 绝大多数高中学校并没有为英语人文教学设置第二课堂。

\section{2 提升高中英语教学人文素质培养的原则}

2. 1 提倡人文关怀

人文关怀是对精神世界的关怀与尊重, 加强人文关怀能 够加强学生参与学习活动的信心与兴趣, 帮助学习树立正确 的价值观和人生观。新形势下的高中英语教学工作应当充分 尊重学生的主体地位, 提升人文素质培育占整体教学工作的 比重, 使学生们的自主能力得到充分的发挥, 强调个体思维 能力的培训。另外, 任课教师也应当对学生的个性化差异保 持更多的关注, 从学生自身情况的角度出发有针对性地制定 教学策略, 给予学生内心世界更多的关注, 关爱学生, 鼓励学 生, 让学生以更加自信的心态参与英语课堂学习活动, 提高 学生的英语能力 ${ }^{[6]}$ 。 


\section{2 比较教学原则}

英语中蕴含有丰富的文化内涵, 高中生在学习英语的过 程中不难发现其中的文化特点与内在涵养。而中华文化和西 方文化之间的差异又直接体现在语言上, 任课教师在日常教 学工作中, 应当更多地以对比的方式来衡量中西文化之间的 差异, 这样更加有利于去其糟粕, 取其精华, 即能够提升学生 的英语知识水平, 同时也有利于培养学生的辩证性思维。

2. 3 循序渐进的原则

无论是教育机构还是任课教师, 首先需要认识到, 通过 英语教学来提升学生的人文素质是一个长期的过程。因此, 在日常的教学工作中望海潮遵循循序渐进的原则, 多多开展 以文人素养教育为核心的英语课外活动, 使学生在长期参与 课外活动的过程中逐渐加深对于英语文化的了解, 从长远的 角度出发来培养学生的人文素质。

\section{3 提升学生人文素质的策略}

3. 1改变传统教学观念与教学方法

要想将人文素质培训与高中英语教学有机结合起来, 首 先要对以往的教学观念进行适当的调整, 对以往陈旧的教育 方式进行有针对性地更新, 将提升学生的综合素质作为教学 重点 ${ }^{[7]}$ 。在课堂教学方面, 任课教师一方面要充分发挥以往 在语法、单词等方面的教学优势, 同时也要加强对学生英语 技能方面的重视力度, 与学生一起深度挖掘英语国家的文化 内涵, 对比中西方的文化差异, 批判性地吸收西方文化的先 进内涵。对传统的教学关系进行适当的调整, 提升高中英语 教学的现代化水平。在教学方法方面, 可多多引入数字化的 教学技术, 以更加立体化的形式展示教学内容, 提高教学效 率, 为学生人文素质的培训创造更多的时间。

\section{2 提升教师的人文素质}

提供学生人文素质,一方面需要对传统的教学观念进行 调整, 更新教学方式, 任课教师也要不断提升自身的人文素 质水平, 不断提升教学质量。因此, 英语教师应当加强对于英 语国家文化特点的了解, 储备相应的人文知识与社会知识, 将这些知识融合在日常的英语教学工作中, 同时发挥教师自 身知识储备与英语教材两方面的作用。另外, 高中教育机构 也应当加强针对英语教师的专业培训工作, 即要优化英语教 师的知识结构, 也要强化英语教师的理论知识应用能力, 为
学生人文素质的提升奠定良好的人才基础。

3. 3挖掘教材中的人文内涵

新形势下的高中英语教学工作, 要求任课教师对教材中 的人文内涵进行深入的挖掘与广泛的延伸, 对英语中所蕴含 的文化内含进行全面的分析, 了解英语国家的文化习惯和思 维表达方式, 将教材中的课文主题与文化内涵有机结合起来, 通过英语课堂教学活动向学生渗透英语文化教育。另外, 任 课教师应当积极引导学生多多思维, 对英语文章中体现出来 的表达方式进行对照分析, 了解英语与汉语之间的思维逻辑 差异, 在此基础上分析中国与英语国家之间在价值取向方面 的差异, 取长补短, 使学生的人文素养得到进一步的丰富与 完善。

\section{4 结束语}

在新课程改革的背景下, 学生综合素质的提升受到学校 的高度重视。为加强学生的人文素养, 高中英语教学应积极 遵循人文关怀原则、比较教学原则、循序渐进原则。同时, 高中英语教学应积极更新教学观念, 提高教师的人文素养, 深入挖掘教材中的人文内涵, 营造良好的人文环境, 丰富第 二课堂。在英语教学中加强培养学生的人文素养不仅有利于 提高学生的综合素质, 而且对我国社会发展有着重要意义。

\section{[参考文献]}

[1]陈淋淋.论高中英语的人文性特点及其教学优化设 计[J].才智,2019,(20):163.

[2]王蓄.从综合语言运用能力到英语学科核心素养— 高中英语课程改革的新挑战 [J]. 英语教师,2015,15(16):6-7.

[3]欧阳丽华.如何在高中英语教学中渗透人文素质的培 养[J].英语教师,2016,16(02):75-76.

[4]孙潋.高中英语的人文性特点及其教学呈现策略 [J]. 安庆师范学院学报(社会科学版),2012,31(01):166-168.

[5]喻又芳.浅谈高中英语教学中学生人文素养的培养 [J].英语广场,2017,(01):166-167.

[6]王燕.数字化环境下高中英语教学人文素养培育现状 研究[J].数字教育,2017,3(06):169-174.

[7]焦玉奎.如何在高中英语教学中培养学生的人文素养 [J].西部素质教育,2018,4(11):182. 